\title{
Antibakteriyel gargara kullanımına bağlı diş renklenmesinin farklı beyazlatma teknikleri ile giderilmesi ${ }^{*}$
}

\author{
Zeynep Fatma Zor(0000-0001-9647-4101) ${ }^{\alpha}$, PInar Çevik(0000-0003-1970-7543) ${ }^{\beta}$
}

Selcuk Dent J, 2018; 5: 218-224 (Doi: 10.15311/selcukdentj. 311303)

Başvuru Tarihi: 09 Mayıs 2017 Yayına Kabul Tarihi: 23 Mayıs 2018

\section{öz}

Antibakteriyel gargara kullanımına bağlı diş renklenmesinin farklı beyazlatma teknikleri ile giderilmesi

Amaç: $\mathrm{Bu}$ çalışmanın amacı, farklı ağız gargaralarının diş yüzeyinde renklendirici etkisini değerlendirmek ve renk değişimine uğramış diş yüzeyinde beyazlatıcı ajan ve iki farkı polisaj işleminin renk açıcı etkilerini kıyaslamaktır.

Gereç ve Yöntemler: Yüz yirmi adet çekilmiş yirmi yaş dişi farklı ağız gargaralarının değerlendirilmesi için dört ayrı gruba (Izotonik, Klorhex, Polividon iyot, Benzidamin hidroklorür) ayrılmıştır $(n=30)$. Her bir gargara grubu kullanılan beyazlatıcı ajan, polisaj patı ve pomza uygulaması için 10'ar örnekli üç ayrı alt gruba ayrılmıştır. Işlem öncesi, gargara uygulamasından sonra ve renk açıcı işlemler sonrası renk analizleri bir dijital spektrofotometre kullanılarak yapılmıștır. Örneklere ait $\Delta \mathrm{L}^{*}, \Delta \mathrm{a}^{*}, \Delta \mathrm{b}^{*}$ ve $\Delta \mathrm{E}$ verileri kaydedilmiştir. Verilerin istatistiksel analizi iki yönlü varyans analizi, tek yönlü varyans analizi ve post-hoc testleri kullanılarak yapılmıştır $(\alpha=0.05)$.

Bulgular: Polividon iyot ve Benzidamin hidroklorür grupları, Klorhex ve Izotonik gruplarından daha yüksek renk değişimine neden olmuştur $(p<0.05)$. Klorhex ve Izotonik grupları arasında renk değişimi açısından anlamlı bir fark yoktur $(p>0.05)$. Beyazlatıcı ajan uygulaması en düşük $\Delta \mathrm{E}$ değeri ile en yüksek renk açıcı etkiye sahiptir $(p<0.05)$. Polisaj patı ve pomza uygulamaları arasında istatistiksel olarak anlamlı bir fark bulunamamıştır $(p>0.05)$.

Sonuç: Uzun süreli gargara kullanımı dişlerde renklenmelere sebep olabilir. Klorheksidin glukonat içeren gargara daha düşük renk değişimine neden olmuştur. Hidrojen peroksit içerikli beyazlatma ajanı en yüksek renk açıcı etkiye sahiptir. Bununla birlikte, polisaj patı uygulaması gargara kullanımı sonrası oluşacak diş renklenmelerinde renk açıcı kolay bir yöntem olarak tavsiye edilebilir.

\section{ANAHTAR KELIMELER}

Diş beyazlatma, dişte renk değişikliği, gargaralar

Diş rengi, dentin rengi ile içsel ve dışsal renk faktörlerinin varlığı ile belirlenebilmektedir. ${ }^{1}$ İçsel renk faktörleri, mine ve dentinin rengi ile bu yapıların ışık kaynağı karşısındaki optik davranışları ile belirlenebilmektedir. ${ }^{2,3}$ Dışsal renk faktörleri,

\section{ABSTRACT}

Removal of dental stains induced by antibacterial mouthwashes by using different bleaching techniques

Background: Tooth discoloration could result from both intrinsic and extrinsic factors. The purpose of this study was to evaluate the effect of different types of mouthwashes on tooth discoloration and the whitening effect of bleaching and polishing procedures on dental stains induced by mouthwashes.

Methods: Extracted human third molars (120) were randomly divided into four groups of 30 specimens each according to the mouthwashes used, i.e., Izotonik, Batticon, Klorhex or Andorex. Each group was further subdivided into three groups of 10 specimens each according to the type of whitening procedure applied; bleaching with hydrogen peroxide, pumice-polishing or polishing paste. Color measurements were taken at baseline, after immersion and following the whitening procedures by using a digital spectrophotometer. $\Delta \mathrm{L}^{*}, \Delta \mathrm{a}^{*}, \Delta \mathrm{b}^{*}$ and total $\Delta \mathrm{E}$ values were recorded. Data were statistically analyzed by using two-way and one-way analysis of variance and post-hoc tests $(p<0.05)$.

Results: It was found that Batticon and Andorex had more staining effect than Klorhex and Izotonik $(p<0.05)$. There was no significant difference between Klorhex and Izotonik. Furthermore, within the same staining groups, both bleached and pumice-polished samples exhibited a greater whitening effect than polishing paste group. There was no significant difference between bleached and pumice-polished samples $(p>0.05)$.

Conclusion: Long-term usage of antibacterial mouthwashes could cause tooth discoloration. It might be beneficial to suggest the less staining effect of mouthwashes in clinical practice. While hydrogen peroxide bleaching has the most whitening effect, pumice-polishing could also be suggested as a practical method after tooth staining induced by mouthwashes.

\section{KEYWORDS}

Tooth bleaching, tooth discoloration, mouthwashes

renklendirici ajana maruz kalan diş minesinin renklendirici materyali ne kadar absorbe ettiği ile ilgilidir. ${ }^{4}$ Mine, dentin ve pulpa yapılarında meydana gelebilecek herhangi bir fiziksel veya kimyasal değişiklik diş rengini doğrudan etkileyecektir. ${ }^{5,6}$

\footnotetext{
${ }^{*}$ Bu çalışma 23-27 Mayıs tarihlerinde Bodrum'da gerçekleştirilen 24. Uluslararası Türk Oral ve Maksillofasiyal Cerrahi Kongresinde sözlü bildiri olarak sunulmuștur.
}

${ }^{\alpha}$ Gazi Üniversitesi, Diş Hekimliği Fakültesi, Ağız Diş ve Çene Cerrahisi Anabilim Dalı, Ankara

$\beta$ Gazi Üniversitesi, Diş Hekimliği Fakültesi, Protetik Diş Tedavisi Anabilim Dalı, Ankara 
Diş yüzeyindeki renklenmelerin giderilebilmesi için en sık kullanılan yöntem, pomza veya leke çıkarıcı patların aşındırıcı etkisinden yararlanarak yapılan leke çıkarma işlemleri veya diş macunu ile yapılan fırçalama işlemleridir. ${ }^{2}$ Diş yüzeyinin pomza, pat gibi maddelerle polisajlanması, diş fırçalama, diş beyazlatıcı ajanların kullanılması, ozon jeli kullanılarak yapılan leke çıkarıcı uygulamalar, dış faktörlere bağlı olarak gelişen diş yüzeyi renklenmelerinde başarılı olarak kullanılabilirler. ${ }^{7}$

Dışsal renklenmeler alınan gıdalar, içecekler veya ağız içi gargaraların kullanımı sonucu oluşabilmektedir. ${ }^{8} \quad$ Dışsal renklenmelerin oluşumunda renklendirici ajanın pH'sı, renklendirici ajana maruz kalma süresi, diş yüzeyinin pürüzlülük düzeyi gibi faktörler renklenme miktarını etkileyebilmektedir. ${ }^{1,7,8}$

Gargara kullanımı sonrası oluşabilecek muhtemel renklenmeler ve bu renklenmeler üzerindeki beyazlatıcı ajan veya polisaj uygulamalarının ne derece etkili olduğu merak konusudur. Dışsal renklenmelerin giderilmesinde pat veya pomza uygulaması genellikle yeterli olmakla beraber hastanın sigara veya renklenmeye sebep olan ajanları kullanmaması, pat veya pomza uygulamasının yeterli olmaması, hasta isteği ya da uzun süreli gargara kullanımına bağlı olarak oluşan dişsal renklenmelerde de beyazlatma ajanları kullanılabilir. Pat ve pomza uygulamasına göre daha etkili olması ve tek uygulamada bile dişlerdeki beyazlatıcı etkilerinin belirgin bir şekilde görülmesi ve buna bağlı gelişen hasta memnuniyeti beyazlatıcı ajanların en önemli avantajları arasındadır. Ancak beyazlatma ajanlarının kullanımı sonrası oluşabilecek dentin hassasiyeti ve çevre yumuşak ve sert dokularda oluşabilecek tahribatlar bu ajanların kullanımındaki en sık görülen dezavantajlardandır. Bu yüzden doğru hasta endikasyonu ve doğru uygulama büyük önem kazanmaktadır. Pat ve pomza uygulamaları genel anlamda yüzeyel lekelenmelerde etkili olduğundan basit lekelenmelerde fazla invaziv olmayan bir teknik olarak uygulanabilir. Ancak dişler üzerinde yüzeyel aşınmalar da yapabildikleri de bilinmektedir. ${ }^{1,2,6}$

Literatürde, farklı tipteki ağız içi gargaraların kullanımı sonucu diş yüzeyinde oluşan renk değişimini ve renklenme üzerine beyazlatıcı tekniklerin etkisini değerlendiren in vitro çalışmaya rastlanmamıştır. Bu çalışmanın amacı, klinikte cerrahi ve periodontal uygulamalar sonrasında sıklıkla kullanılan antibakteriyel gargaraların renklendirici etkisini değerlendirmek; gargara kullanımı sonrası renk değişimine uğramış diş yüzeyinde beyazlatıcı ajan ve polisaj yöntemlerinin renk açıcı etkilerini kıyaslamaktır. Çalışmada, (1) farklı ağız gargaraları farklı oranda dışsal renklenmeye neden olur ve (2) beyazlatma ajanı ve iki farklı polisaj yönteminin renk açıcı etkileri ve iki farklı polisaj yönteminin renk açıcı etkileri arasında fark yoktur hipotezleri test edilmiştir.

\section{GEREC VE YÖNTEM}

Çalışma Gazi Üniversitesi Diş Hekimliği Fakültesi Ağız, Diş ve Çene Cerrahisi Anabilim Dalı ve Protetik Diş Tedavisi Anabilim Dalı'nda gerçekleştirilmiştir. Ankara Üniversitesi Diş Hekimliği Fakültesi Etik Kurul Komisyonu'ndan etik kurul onayı alınmıştır. Yüz yirmi adet çürüksüz ve restorasyonsuz yirmi yaş dişi kullanılmıştır. Çekilmiş dişler 1 hafta süreyle distile su içerisinde bekletilmiştir. Dişler 10'lu gruplar halinde silikon esaslı ölçü materyaline (Speedex, Colthene-Whaledent, CA, USA) kron kısımları açıkta kalacak şekilde gömülmüştür (Resim 1). Bu şekilde 12 adet grup hazırlanmıştır. Çalışma dizaynı ve grupların dağılımı Resim 2'de görülmektedir. Silikon modeller, kullanılacak ağız gargarasına göre rastgele dört ayrı gruba ayrılmıştır (Tablo 1) $(n=30)$. Dişlerin ilk renk ölçümleri dişlerin bukkal yüzeylerinden dijital bir spektrofotometre (VITA Easy shade Compact Advance 4.0, VITA Zahnfabrik, Almanya) kullanılarak yapılmıştır. Her bir dişin ölçüm yapılan bölgesi silikon üzerinde işaretlenerek ölçümlerin her bir diş için aynı bölgeden yapılması sağlanmıştır. Böylece, diş renkleşmesi her bir dişe ve dişin ilgili yüzeyindeki miktarına göre standardize edilmiştir. CIELAB (Commission Internationale de I'Eclairage=Uluslararası Aydınlatma Komisyonu) üç boyutlu renk sistemine göre dişlere ait $L^{*}, a^{*}$ ve $b$ * değerleri kaydedilmiştir.

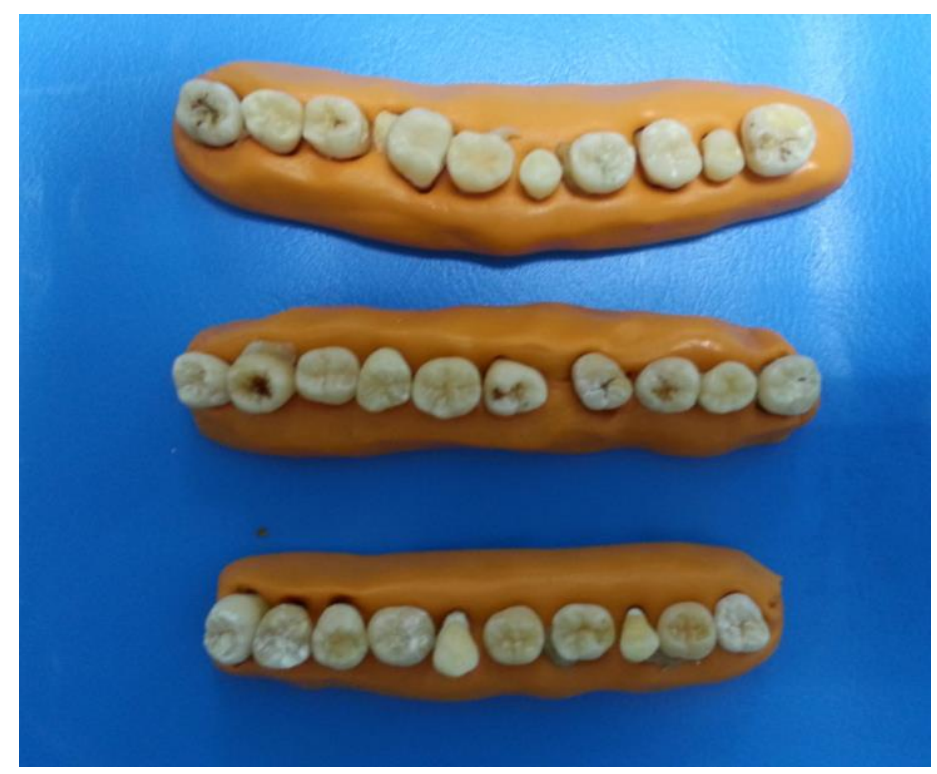

Resim 1.

Çekilmiş dişlerin silikon içerisine yerleştirilmesi (Molar diş haricindeki dişler çalışmaya dahil edilmemiştir)

Ölçüm sonrası dişler kron kısımları tamamen gömülecek şekilde gargaralar içine daldırılmıştır. Solüsyonlar içinde üç hafta boyunca bekletilen dişler, bu süresinin ardından 
solüsyonlardan çıkartılarak musluk suyu altında $10 \mathrm{sn}$ boyunca yıkanmış ve hava su spreyi ile kurutulmuştur.

Tablo 1.

Grupların solüsyona maruz kaldıktan sonraki $\Delta^{*} \mathrm{~L}, \Delta \mathbf{a}^{*}$ ve $\Delta b^{*}$ değerleri

\begin{tabular}{|lll|}
\hline Materyal & íçerik & Üretici firma \\
\hline Batticon & Polividon iyot & Adeka, İstanbul, Türkiye \\
\hline Klorhex & $\% 0.2$ klorheksidin glukonat & Drogsan, Ankara, Türkiye \\
\hline Andorex & $\begin{array}{l}18 \text { mg klorheksidin } \\
\text { glukonat, } 22.5 \mathrm{gr} \\
\text { benzidamin HCl }\end{array}$ & $\begin{array}{l}\text { DeltaVital, İstanbul, } \\
\text { Türkiye }\end{array}$ \\
\hline $\begin{array}{l}\text { İotonik } 0.9 \text { İzotonik sodyum } \\
\text { klorür (serum fizyolojik) }\end{array}$ & $\begin{array}{l}\text { Eczacıbaşı-Baxter, } \\
\text { İstanbul, Türkiye }\end{array}$ \\
\hline $\begin{array}{l}\text { Beyazlatma } \\
\text { ajanı }\end{array}$ & $\begin{array}{l}\text { \% } 6 \text { hidrojen peroksit, eser } \\
\text { miktar karbamid peroksit }\end{array}$ & $\begin{array}{l}\text { Bite\&White, Cavex } \\
\text { Holland BV, Haarlem, } \\
\text { Hollanda }\end{array}$ \\
\hline $\begin{array}{l}\text { Ticari adı } \\
\text { Polisaj patı }\end{array}$ & $\begin{array}{l}\text { \%1.23 flor, 0.1 mol fosfat, } \\
\text { xylitol }\end{array}$ & $\begin{array}{l}\text { Qartz, Dharma Research, } \\
\text { Miami, ABD }\end{array}$ \\
\hline $\begin{array}{l}\text { Ticari adı } \\
\text { Pomza }\end{array}$ & Pomza tozu & $\begin{array}{l}\text { İşler Pomza, İstanbul, } \\
\text { Türkiye }\end{array}$ \\
\hline
\end{tabular}

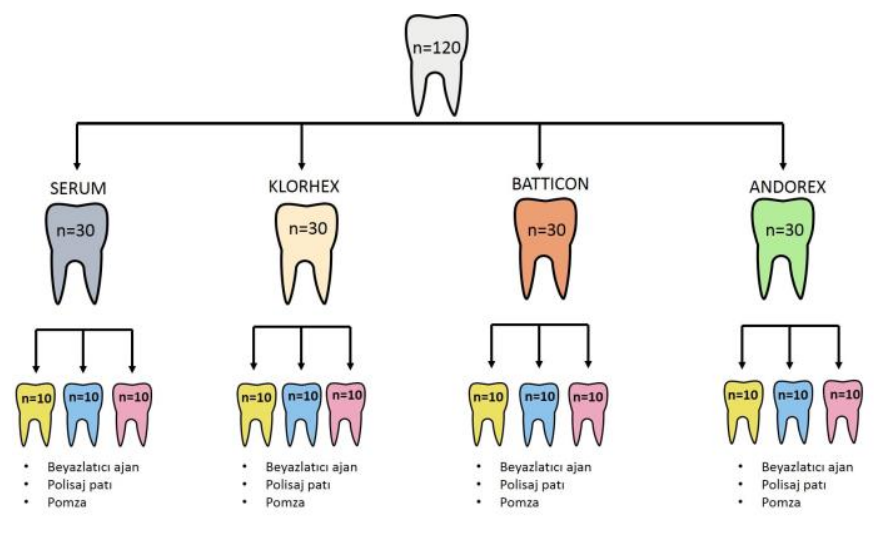

Resim 2.

Çalışma dizaynı ve çalışma grupları

Tablo 2.

Çalışmada kullanılan materyaller ve üretici firmalar

\begin{tabular}{lcccc|} 
Gargaralar & $\mathbf{N}$ & $\mathbf{\Delta L}$ & $\mathbf{\Delta a}$ & $\mathbf{\Delta b}$ \\
\hline Serum & 29 & 1,09 & -0.2 & -2.19 \\
\hline Klorhex & 28 & -0.53 & +0.4 & -2.2 \\
\hline Polividon iyot & 30 & -10.6 & +2.7 & +16.8 \\
\hline Benzidamin hidroklorür & 29 & -6.5 & -17.8 & -4.3 \\
\hline Total & 116 & & & \\
\hline
\end{tabular}

Gargara uygulaması sonrası ikinci renk ölçümleri aynı dijital spektrofotometre ile yapılmıştır (Tablo 2). Her bir dişe ait ikinci $L^{*}, a^{*}$ ve $b^{*}$ değerleri kaydedilerek, gargara uygulaması sonrasında dişlerin renk değişim miktarları hesaplamıştır. Renk ölçümü yapılamayan veya yüzeyinde defekte sahip örnekler çalışma dışı bırakılmıştır (Tablo 3).

\section{Tablo 3.}

\section{İlk ölçümlere ait solüsyon gruplarının total renk değişimine ait $\Delta E$ değerleri}

\begin{tabular}{|lccccc|}
\hline Gargaralar & N & Ortalama & $\begin{array}{c}\text { Std. } \\
\text { Sapma }\end{array}$ & Minimum & Maximum \\
\hline Serum & 29 & $4,01^{\text {a }}$ & 1,9 & 1,08 & 10,58 \\
\hline $\begin{array}{l}\text { Klorhex } \\
\text { Polividon }\end{array}$ & 28 & $4,07^{\text {a }}$ & 2 & 1,41 & 10,36 \\
\hline $\begin{array}{l}\text { iyot } \\
\text { Benzidamin } \\
\text { hidroklorür }\end{array}$ & 29 & $23,82^{\text {b }}$ & 14,3 & 7,42 & 89,79 \\
\hline \begin{tabular}{l} 
Total \\
\hline
\end{tabular} & 116 & & 7,2 & 8,36 & 41,06 \\
\hline
\end{tabular}

Not: Farklı üst simgeyi taşıyan aynı sütundaki değerler arasındaki fark istatistiksel olarak anlamlıdır $(p<0.05)$.

Her bir solüsyon grubundaki örnekler, kullanılacak beyazlatma yöntemine göre üç alt gruba ayrımıştır (Resim 2, $n=10$ ). Beyazlatma ajanındaki grubu örnekleri, üretici firmanın talimatları doğrultusunda 1 saat boyunca beyazlatma işlemine tabi tutulmuştur. Polisaj patı ve pomza gruplarında, örneklere 10 sn boyunca döner alet yardımıla pomza veya pat uygulanmıştır. İşlem sonrası tüm örnekler musluk suyu altında 10 sn boyunca yıkanmış ve hava su spreyi ile kurutulmuştur. Dişlerin üçüncü renk ölçümleri aynı dijital spektrofotometre kullanılarak yapılmıştır. Çalışma sonunda, her bir dişe ait gargara uygulaması öncesi, gargara uygulaması sonrası ve beyazlatma işlemleri sonrasına ait $L^{*}$, $a^{*}$ ve $b^{*}$ değerleri elde edilmiştir. Örneklerin renk değişimlerine ait $\Delta \mathrm{E}$ değerleri istatistiksel olarak analiz edilmiştir (Tablo 4).

Tablo 4.

Beyazlatma işlemi sonrası renk açıcı ajanların total renk değişimine ait $\Delta \mathrm{E}$ değerleri

\begin{tabular}{|lccccc|}
$\begin{array}{l}\text { Renk } \\
\text { Açıcı } \\
\text { Ajanlar }\end{array}$ & N & Ortalama & $\begin{array}{c}\text { Std. } \\
\text { Sapma }\end{array}$ & Minimum & Maximum \\
\hline Pat & 38 & $\begin{array}{c}12,61^{\mathrm{b}} \\
8,7\end{array}$ & 1,48 & 31,5 \\
\hline Pomza & 39 & $\begin{array}{c}11,76 \\
\text { ba }\end{array}$ & 7,4 & 1,99 & 36,17 \\
\hline Total & 116 & & & & \\
\hline
\end{tabular}

Not: Farklı üst simgeyi taşıyan aynı sütundaki değerler arasındaki fark istatistiksel olarak anlamlıdır $(p<0.05)$. 


\section{İstatistiksel Analiz}

Veriler istatistik paket programı (SPSS Version 20.0; SPSS Inc., Chicago, IL, ABD) kullanılarak analiz edilmiştir. Kullanılan gargara solüsyonları ve renk açma işlemlerinin renk değişimine olan etkisi iki yönlü varyans analizi (ANOVA), tek yönlü ANOVA ve grupların çoklu karşılaştırmaları için Tamhane's T2 testi kullanılarak değerlendirilmiştir. Analizlerde anlamlıık düzeyi $p<0.05$ olarak seçilmiştir.

\section{BULGULAR}

İki yönlü ANOVA testi dört renk değişimi açısından gargara solüsyonları arasında anlamlı fark olduğunu göstermiştir $(p<0.05)$. Polividon iyot grubu ile Benzidamin hidroklorür grupları arasında renk değişimi açısından anlamlı bir fark görülememiştir ( $p>0.05)$. En az renk değişimi, Izotonik grubunda bekletilen örneklerde gözlenmiş olup Klorhex grubu ile Izotonik grupları arasında renk değişimi açısından istatistiksel olarak anlamlı bir fark bulunamamıştır (p>0.05) (Tablo 3).

Örneklerin gargara solüsyonlarında bekletildikten sonra elde edilen $\Delta L^{*}, \Delta a^{*}$ ve $\Delta b^{*}$ değerleri Tablo 2'de belirtildiği gibidir. Gargara uygulaması sonrası Polividon iyot solüsyon grubunun $\Delta L$ değeri en düşük değerde olup negatif yönde değişim olduğu gözlenmiştir. Polividon iyot grubu yine en yüksek $\Delta \mathrm{b}^{*}$ değerini $(+16.8)$ vermiştir. Çalışmada en düşük $\Delta a^{*}$ değeri Benzidamin hidroklorür grubuna ait olup negatif yönde (-17.8) $\Delta \mathrm{a}^{*}$ değerindedir. Çalışmada, Izotonik ve Klorhex gruplarının $\Delta \mathrm{L}^{*}$, $\Delta a^{*}$ ve $\Delta b^{*}$ değerlerinin birbirine yakın sonuçlar verdiği gözlenmiştir.

Örneklerin üçüncü ölçümleri sonrasında beyazlatıcı ajanların renk açıcı etkisinin değerlendirildiği sonuçlara göre, renk açıcı ajanlar arasında, gargara solüsyonlarından bağımsız olarak istatistiksel anlamlı bir fark bulunmuştur $(p<0.05)$. Buna göre, tüm gruplar için, en düşük $\Delta \mathrm{E}$ değerinin diş beyazlatıcı ajanın kullanıldığı Cavex grubunda kaydedilmiş olduğundan, en yüksek renk açıcı etkinin beyazlatıcı ajan grubunda olduğu gözlenmiştir. Bununla birlikte, pomza ve beyazlatıcı ajan Cavex arasında renk değişimi açısından anlamlı bir fark bulunmazken, polisaj patı grubunun $\Delta \mathrm{E}$ değeri pomza ve beyazlatıcı ajanın $\Delta E$ değerlerinden anlamlı derecede düşük bulunmuştur. $(p<0.05)$. Bu sonuçlara göre, en düşük renk açıcı etkinin polisaj patının kullanılığı grupta olduğu sonucuna varılmaktadır (Tablo 4).

\section{TARTIŞMA}

Diş hekimliğinde ağız gargaraları; koruyucu ve tedavi edici, bazı profesyonel işlemlere yardımcı olması amacıyla kullanılmaktadır. Değişik içerik ve şekilde piyasaya sunulan ağız gargaraları hekimler ve hastalar tarafından kolay uygulanabilmesinden dolayı koruyucu tedavinin önemli bir safhasını oluşturmaktadır. Antibakteriyel etkinlikleri ile ağız florasının ve ağız kokusunu azaltmada, çürükten ve periodontal hastalıktan korunmada, cerrahi operasyonların ağız mukozasında yol açtığı zararlı etkilerin azaltımasında yardımcı olurlar. ${ }^{2,9,10}$

Hollanda'da yapılan bir çalışmada, dişlerdeki yüzeyel renk değişikliğine sebep olan ilaçların \%85'inin antibiyotik ve antimikrobiyal içerikli olduğu bildirilmiştir. ${ }^{11}$ Farklı yapıda olan ve dişler üzerinde renklendirici etkisi olduğu bilinen pek çok farklı gargara çeşidi bulunmaktadır. Ancak bu etkileri kısa süreli kullanımda görülmez. ${ }^{12-14}$ Çalışmada tüm gruplardaki dişler normal kullanım süresinden daha uzun süre (21 gün) gargaraların içinde bekletilerek uzun sureli kullanımlarındaki renklenme dereceleri değerlendirilmiştir.

Klinik uygulamada gargara kullanımı genellikle 7-10 gün arası olmakla beraber gargaraların daha uzun süre kullanılmasını gerektiren klinik durumlar da vardır. Kemoterapi veya radyoterapi alıp ağzında stomatitis tarzı lezyonların oluştuğu durumlarda, ağız hijyenini herhangi bir nedenle sağlayamayan hastalarda, osteomiyelitte, bifosfanata bağlı osteonekrozlarda klinik duruma göre daha uzun süreli kullanım gerekebilir. Bununla beraber farklı tip gargaralarda farklı kullanım süreleri de sözkonusudur. Örneğin listerin gibi fenol bileşimi gargaralarda 6 haftalık kullanım önerilirken, hiyolüronik asit içerikli gargaraların da uzun süreli kullanımı uygundur.

Bu çalışmada diş hekimliği pratiğinde ve cerrahi operasyonlar sonrası sıkça kullandığımız antibakteriyel özellikli gargaraların (Izotonik, Polividon iyot, Klorhex, Benzidamin hidroklorür) dişler üzerindeki renklendirici etkisi değerlendirilmiştir. Dişler üzerinde en çok renklendirici etkiye sahip ajanın polividon iyot içeren Polividon iyot olduğu, en az renklendirici etkiye sahip ajanın da serum fizyolojik esaslı Izotonik olduğu tespit edilmiştir. Bu nedenle, çalışmamızdan elde edilen sonuçlar çalışma başında kurulan sıfır hipotezini destekler niteliktedir.

Kullanılan ajanların bazıları oksidasyon etkisine sahipken bazıları abrazivdir, diğerleri bu ajanların kombinasyonudur. Günümüzde en sık kullanılan beyazlatıcı ajan ise hidrojen peroksit ve karbamid peroksittir. ${ }^{15,16}$ Genellikle, hidrojen peroksit \%3-40 konsantrasyon aralıginda, karbamid peroksit ise \%1-45 konsantrasyon aralığnda kullanılmaktadır. ${ }^{17,18}$ Çalışmamızda kısmi karbamid peroksit içeren \%6 hidrojen peroksit konsantrasyonunda beyazlatma ajanı kullanılmış ve renk açıcı etkisi pat ve pomzadan daha yüksek oranda bulunmuştur. Çalışmadan elde edilen sonuçlara göre kimyasal etkili beyazlatıcı ajanın mekanik aşındırma etkisi olan pat ve pomzadan renk açıcı etkisinin daha yüksek olduğu sonucu çıkartılabilir. 
Beyazlatma tedavisinde uygun yöntemin seçilmesi başarıyı doğrudan etkileyen bir unsurdur. Kullanılan kimyasal ajanlar ve özel uygulama şekilleri, renklenmenin tipi, derecesi ve yerine bağlı olarak farklııklar göstemektedir. Dış kaynaklı renklenmeler dişler ağız ortamına sürdükten sonra oluşmaktadır. Ağız yoluyla alınan gargaralar veya ilaçlar genellikle yüzeyel diş renklenmelerine neden olur ve diş firçalama ya da profesyonel bakım ile temizlenebilir. Çalışmamızdan elde edilen sonuçlara göre gargara kullanımına bağlı olan diş renklenmelerinde renk açıcı olarak en etkili yöntemin hidrojen peroksit ile diş beyazlatma uygulamaları olduğu yorumu yapılabilir.

Çalışmamızda polisaj patı kullanılan örneklerin $\Delta E$ renk değişimi miktarı tüm gruplarda hidrojen peroksit içeren beyazlatma ajanına göre anlamlı derecede yüksek çıkmıştır. Bu sonuçlara göre, gargaralardan bağımsız olarak, diş yüzeyinde beyazlatma ajanının etkisinin polisaj patına göre daha etkin olduğu sonucuna varılabilir. $\mathrm{Ne}$ var $\mathrm{ki}$, pomza ile beyazlatma ajanı arasında $\Delta \mathrm{E}$ renk değişimi açısından anlamlı bir fark bulunmaması nedeniyle, aşındırıcı etkisi yüksek olan pomzanın da gargara kullanımı sonrasındaki renklenmelerde renk açıcı olarak kullanılabileceği yorumu yapılabilir.

Çalışmamızda renk değişimleri CIELAB sistemi esas alınarak yapılmıştır. CIELAB sisteminde $L^{*}$ değeri renkteki açıklığı ifade ederken $\Delta L^{*}$ değerindeki pozitif yöndeki artış renkteki açıklık miktarının artmasını ifade ederken negatif yöndeki artış ise rengin koyulaştığını ifade etmektedir. CIELAB sistemindeki $a^{*}$ değeri yeşilden kırmızıya doğru olan renk değişimini, $b^{*}$ değeri ise sarıdan maviye olan renk değişimini ifade eder. ${ }^{18} \Delta \mathrm{a}^{*}$ değerindeki pozitif yöndeki artış rengin kırmızı yöndeki artışını, negatif yöndeki artış ise rengin yeşil yönündeki artışını ifade eder. $\Delta b^{*}$ değerindeki pozitif yöndeki artı̧̧ rengin sarı yönünde değişimini, $\Delta b^{*}$ değerindeki negatif yöndeki artış ise rengin mavi yönüne doğru değişimini ifade etmektedir. ${ }^{19}$

Çalışmamızda, gargara kullanımı sonrasında dişlere ait $\Delta \mathrm{L}^{*}, \Delta \mathrm{a}^{*}$ ve $\Delta \mathrm{b}^{*}$ değerleri kaydedilmiştir. Buna göre, polivinil iyot grubunun pozitif yönde $\Delta b^{*}$ değerindeki artışı, dişlerin sarı renginin artmasıyla sonuçlanmışıı. Yine polivinil iyot grubunun $\Delta L^{*}$ değerindeki negatif artış örneklerin polivinil iyot sonrası koyulaştığını da göstermektedir. Çalışma sonunda en yüksek $\Delta \mathrm{E}$ renk değişim miktarının polivinil iyot grubunda gözlenmesi bu gruptaki örneklerin hem $\Delta L^{*}$ hem de $\Delta b^{*}$ değerlerindeki belirgin artışa bağlı olduğu söylenebilir. Bununla beraber, benzidamin hidroklorür ile klorheksidin glukonat grubundaki $\Delta \mathrm{a}^{*}$ değerinin negatif yöndeki artışı dişlerin yeşile doğru renginin değiştiğini göstermektedir. Örneklerdeki renk değişimleri, araştırmacılar tarafından gargaralardan çıkarılan örneklerde de gözlenmiştir (Resim-3).

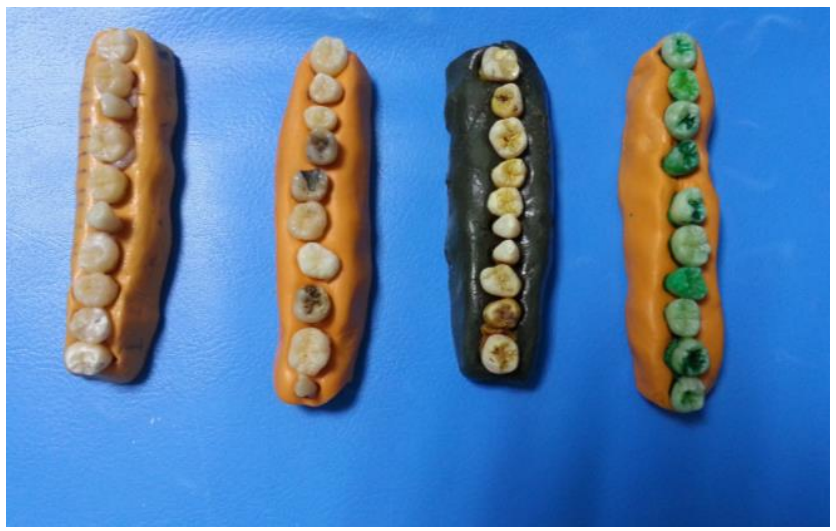

Resim 3.

Gargara kullanımı sonrası diş örnekleri (Soldan sağa; izotonik sodyum klorür, klorheksidin glukonat, polividon iyot, klorheksidin glukonat-benzidamin hidroklorür)

Klorheksidin benzeri antibakteriyel ajanların renklendirici etkisinin incelendiği çalışmalarda, enzimatik olmayan bir dizi reaksiyon sonucunda diş renginin koyulaştığı bildirilmiştir. ${ }^{7,20}$ Antibakteriyel ajanların renklendirme etkisinin değerlendirildiği ilk dönem çalışmalara göre, antibakteriyel ajanların leke yapıcı özellikleri birkaç sebebe bağlı olarak gelişmektedir. Bunlar; birçoğu katyonik özellikte olan antibakteriyel ajanların diş-dişeti birleşiminde $\mathrm{pH}$ 'ın düşüşüne sebep olarak renklenmeye sebep olması, fosfoproteinlerle etkileşime giren antibakteriyel ajanların hidroksiapatit kristallerinde artışa sebep olarak renklendirmeyi tetiklemesi, renkli olan herhangi bir antibakteriyel varlığında hidroksiapatit kristallerinin hacimce genişleyerek renkli maddeyi absorbe etmesi ile renklenmenin diş yüzeyinde de başlaması şeklinde sayılabilir. ${ }^{7,8,20} \mathrm{Bu}$ nedenler dikkate alındığında, çalışmamızda en çok renk değişimine neden olan polividon iyot ve klorheksidin glukonat-benzidamin hidroklorür gargaralarına bağı renklenmenin hidroksiapatit kristallerinin renkli maddeyi absorbe etmesine bağlı olarak geliştiği yorumu yapılabilir. Bununla beraber, klorheksidin glukonat grubunun izotonik sodyum klorür ile benzer renk değişimi sonuçları vermesi ile, renkli madde içermeyen klorheksidin glukonatın uzun süreli kullanımında renklenmeye sebep olmayacağı söylenebilir. illk dönem çalışma sonuçlarına göre, klorheksidine bağı renklenmelerin ağız içindeki enzimatik reaksiyonların elimine edilmesi ile engellendiği düşünüldüğünde, dental plak ve bir dizi enzimatik reaksiyonun var olduğu ağız ortamında bu tip gargaraların renklendirme davranışları hakkında kesin bir yorum yapilamaz. 
Beyazlatma tedavisinde uygun yöntemin secilmesi başarıyı doğrudan etkileyen bir unsurdur. Kullanılan kimyasal ajanlar ve özel uygulama şekilleri, renklenmenin tipi, derecesi ve yerine bağlı olarak farklılıklar göstermektedir. Ağız yoluyla alınan gargaralar veya ilaçlar genellikle yüzeyel diş renklenmelerine neden olur ve diş fırçalama ya da profesyonel bakım ile giderilebilir. Günümüzde kullanılan beyazlatma ajanların bazıları oksidasyon etkisine sahipken bazıları abrazivdir, bir kısmı bu ajanların kombinasyonunu içermektedir. Günümüzde en sık kullanılan beyazlatıcı ajanlar hidrojen peroksit ve karbamid peroksit içermektedir. ${ }^{16}$ Hidrojen peroksit \%3-40 konsantrasyon aralı̆ı̆ında, karbamid peroksit ise \%1-45 konsantrasyon aralığında kullanılmaktadır. ${ }^{17,18}$ Çalışmamızda eser miktarda karbamid peroksit içeren, \% 6 hidrojen peroksit konsantrasyonunda beyazlatma ajanı kullanılmıs ve renk açıcı etkisinin mekanik aşındırma etkisi olan polisaj patı ve pomzadan daha yüksek olduğu saptanmıştır. Bu nedenle çalışmanın ikinci hipotezinin reddi uygundur.

Literatürde dışsal renklenmelerin oluşumunda sıklıkla çay, kahve, kırmızı şarap gibi renklendirici etkisi olan içeceklerin diş veya kompozit yüzeyindeki renklendirme miktarları araştııımıştır. ${ }^{6,21-23} \mathrm{Ne}$ var $\mathrm{ki}$, yiyecek-içecek maddelerine bağlı gelişen renklenme olayı antibakteriyel ajan kullanımına bağlı yukarıda sayılan olası nedenlere bağlı olarak gelişen renklenmelerden farklıdır. Yiyecekiçeceklere bağlı gelişen renklenmede iyon değişimi varlığından söz edilir. Bu renklenme tipinde, pelikıl yüzeyindeki iyonların yiyecek-içecek maddesindeki iyonlar ile yer değiştirmesi ile renklenmenin oluştuğu düşünülmektedir. ${ }^{8,26}$ Böylece, yiyecek-içecek renklenmesi elektrostatik bir çekim yasası ile oluştuğundan, aşındırıcı maddeler veya diş macunu gibi yüzey-aktif ajanlar ile yüzeyden kolayca uzaklaştırılabilir. ${ }^{27,28}$ Daha önce bahsedildiği gibi antimikrobiyal ajanların fosfoproteinler ile etkileşime girmesi, hidroksiapatit kristallerinin direkt olarak renklenmede rol almaları ve pH'daki değişiklikler gargaralara bağlı renklenmeden sorumlu faktörlerdir. $\mathrm{Bu}$ noktada, gargaraların dişler üzerindeki renklendirici etkisi ve gargara kullanımı ile renklendirilmiş olan diş yüzeylerinde renk açıcı ajanların etkinliğinin değerlendirildiği bu çalışma, diğer araştırmalardan farklılık göstermektedir. Çalışmamızda kullanılan dişlerin beyazlatıcı uygulamalar öncesi ve sonrasındaki yüzey pürüzlülüğü miktarlarının değerlendirilmemesi, yalnızca dört farklı çeşit gargara tercih edilmesi çalışmamızın limitasyonlarını oluşturmaktadır. Gelecekteki çalışmalarda, pelikıl varlığının ve antibakteriyel ajanların $\mathrm{pH}$ derecelerinin renklendirmeye etkisi değerlendirilebilir. Ayrıca farklı gargara solüsyonları, farklı içerikte diş beyazlatıcı ajanlar ve polisaj materyalleri kullanılarak, bu materyallerin dişler üzerindeki farklı fiziksel etkileri değerlendirilebilir.

\section{SONUÇ}

Çalışmadan elde edilen sonuçlara göre, polividon iyot içerikli Batticon ve benzidamin hidroklorür ile klorheksidin glukonat içeren Andorex gargaraların diş yüzeyinde belirgin renklenmeye neden olabileceği klinik uygulamalarda dikkate alınmalıdır. Renklenmiş diş yüzeyleri üzerinde en yüksek beyazlatıcı etki hidrojen peroksit içeren beyazlatıcı ajan yardımıyla elde edilmiştir. Bununla beraber, pomza ile diş yüzeyinin polisajlanmasının da klinik açıdan uygulanabilecek kolay ve etkin bir yöntem olduğu söylenebilir. 


\section{KAYNAKLAR}

1. Dahl JE, Pallesen U. Tooth bleaching-a critical review of the biological aspects. Crit Rev Oral Biol Med 2003; 14: 292-304.

2. Plotino G, Buono L, Grande NM, Pameijer CH, Somma F. Nonvital tooth bleaching: a review of the literature and clinical procedures. J Endod 2008; 34: 394-407.

3. Hattab FN, Qudeimat MA, al-Rimawi HS. Dental discoloration: an overview. J Esthet Dent 1999; 11: 291-310.

4. Jahangiri L, Reinhardt SB, Mehra RV, Matheson PB. Relationship between tooth shade value and skin color: an observational study. J Prosthet Dent 2002; 87: $149-52$.

5. Ten Bosch JJ, Coops JC. Tooth color and reflectance as related to light scattering and enamel hardness. J Dent Res 1995; 74: 374-80.

6. Joiner A, Jones NM, Raven SJ. Investigation of factors influencing stain formation utilizing an in situ model. Adv Dent Res 1995; 9: 471- 6.

7. Azarpazhooh A, Limeback H. The application of ozone in dentistry: a systematic review of literature. J Dent 2008; 36: 104-116.

8. Nathoo SA, Gaffar A. Studies on dental stains induced by antibacterial agents and rational approaches for bleaching dental stains. Adv Dent Res 1995;9: 462-470.

9. Addy M, Moran J, Griffiths AA, Wills-Wood NJ. Extrinsic tooth discoloration by metals and chlorhexidine. Surface protein denaturation or dietary precipitation? Br Dent J 1985; 159: 281-285.

10. WattsA, Addy M. Tooth discoloration and staining: a review of the literature. Br Dent J 2001;190:309-16

11.Redwin CJ, Scully C, Bagan-Sebastian JV. Druginduced disorders of teeth. J Dent Res 2005; 84: 596602.

12. Bringhtman LJ, Terezhalmy GT, Greenwell H, Jacobs M, Enlow DH. The effects of a $0.12 \%$ chlorhexidine gluconat mouthrinse orthodontic patients aged 11 through 17 with established gingivitis. Am J Orthod DentofacOrthop 1991; 100: 324-9.

13. Ciancio SG. Antiseptics and antibiotics as chemotherapeutic agents for periodontitis management. Compend Contin Educ Dent 2000; 5978.

14.Fardal O, Tumbull RS. A rewiew of the literature on use of chlorhexidin in dentistry. JADA 1986; 112: 863-9.

15.Rodrigues JA, Marchi GM, Ambrosano GM, Heymann HO, Pimenta LA. Microhardness evaluation of in situ vital bleaching on human dental enamel using a novel study design. Dent Mater 2005; 21: 1059-67.
16. Lorenzo JA, Navarro LF, Caballero AB. At- home vital bleaching: a comparison of hydrogen peroxide and carbamide peroxide treatments. Med Oral Patol Oral Cir Bucal 2006;11: 94-9.

17. Sarrett DC. Tooth whitening today. J Am Dent Assoc 2002; 133: 1535-8.

18. Bayındır F, Kürklü D, Yanıkoğlu DN. The effect of staining solutions on the color stability of provisional prosthodontic materials. J Dent 2012; 40: 41-46.

19.Nielsen S. Food Analysis: Color Analysis in Physical properties of foods. Wrolstad RE, Smith DE, editors. Food Analysis. Springer International Publication; 2009. p. 583.

20.Gaffar A, Donohue JJ, Davis CB, Carroll DL. Studies on antibacterially induced staining of teeth (abstract). J Dent Res 1979; 58(Spec Iss): 467.

21.Ren YF, Feng L, Serban D, Malmstrom HS. Effects of common beverage colorants on color stability of dental composite resins: the utility of a thermocycling stain challenge model in vitro. J Dent 2012; 40 Suppl 1: e48-56.

22.Lee RJ, Bayne A, Tiangco M, Garen G, Chow AK. Prevention of tea-induced extrinsic tooth stain. Int J Dent Hyg 2014; 12: 267-72.

23. Kumari RV, Nagaraj H, Siddaraju K, Poluri RK. Evaluation of the Effect of Surface Polishing, Oral Beverages and Food Colorants on Color Stability and Surface Roughness of Nanocomposite Resins. J Int Oral Health 2015; 7: 63-70.

\section{Yazışma Adresi:}

Doç.Dr. Pınar ÇEViK

Gazi Üniversitesi Diş Hekimliği Fakültesi

Protetik Diş Tedavisi AD

Bişkek Cd. 82. Sokak No:4

06510, Emek, Çankaya, Ankara

Tel : +90 3122034192

E-mail: dt_pinarcevik@yahoo.com 